\title{
A biography of memory: layered memorialisation of military death at an urban cenotaph
}

\author{
Yvonne Inall
}

Abstract: Established memorials have a way of attracting new memorials to their proximity. The act of embedding a new memorial into an existing commemorative space transfers to the new monument a sense of the weight of memory and commemorative potency of the preceding monuments. The new monument is also legitimised through its acceptance or incorporation into a recognised place of memory and commemoration. Furthermore, memorialising activities play an important role in the formation of group identities and collective memory, which may also be contested or renegotiated over time. This article presents a biographical exploration of this process of layered memorialisation using the war memorials situated in Paragon Square, Kingston Upon Hull, in East Yorkshire as a case study.

Keywords: War memorials, commemoration, memorialisation, collective memory, places of memory.

Note on the author: Yvonne Inall is an archaeologist who was a Postdoctoral Research Associate on the AHRC-funded project 'Remember Me the Changing Face of Memorialisation', at the University of Hull. She is now a Project Officer at the Australian Archaeological Institute at Athens, based at the University of Sydney. She also holds an Honorary Research Fellowship at the University of Hull.

Recent publications:

Inall, Y. (2019), 'New Light on Warfare in Iron Age Britain', in P. Halkon (ed.) The Arras Culture of Eastern Yorkshire: Celebrating the Iron Age (Oxford, Oxbow).

Macleod, J. \& Inall, Y. (2020), 'A Century of Armistice Day: Memorialisation in the Wake of the First World War', Mortality, 25(1): 48-68. https://doi.org/10.1080/13576275.2019.1611752

Inall, Y. \& Lillie, M. C. (2020), 'Meaning and Mnemonic in Archaeological Studies of Death and Memorialisation', Mortality, 25(1): 7-24. https://doi.org/10.1080/13576275.2019.1589441

(C) The author(s) 2020. This is an open access article licensed under a Creative Commons Attribution-NonCommercial-NoDerivs 4.0 Unported License 


\section{INTRODUCTION}

The desire to memorialise the dead appears to be a persistent human need, and is one which occurs from the structured burials undertaken by early anatomically modern human populations through to the contemporary world. ${ }^{1} \mathrm{~A}$ recurrent feature in memorialising activity is the practice of situating new memorials in close proximity to extant memorial structures or features. At prehistoric sites in Britain, for example, it is possible to observe Bronze Age monuments intersecting with earlier Neolithic longbarrows, and in turn these become the foci of Iron Age, Romano-British, and, later, Anglo-Saxon era monuments. ${ }^{2}$ In the modern world a similar layering of commemoration is visible, for example, at Parliament Square in London, where a series of statues to prominent men (and most recently a woman) have been erected from the 1830 s to 2018 . Throughout the 20th century, the memorialisation and commemoration of casualties of war, in particular, became highly visible, particularly following the First World War (1914-18), ${ }^{3}$ and with subsequent conflicts including the Second World War (1939-45), Korean War (1950-3), Vietnam War (1955-75), Falklands War (1982), First Gulf War (1991), and more recent conflicts in Afghanistan and Iraq from 2001 onwards. A layering of military memorialisation is a notable feature at national commemorative sites, such as Arlington National Cemetery and Washington DC in the United States, the National Arboretum in the United Kingdom, or Anzac Parade in Australia's national capital, Canberra.

Memorialisation in a national capital can offer insights into how a nation sees itself, and the monuments in these locations receive a great deal of attention from their planning stages through to the large numbers of visitors who attend the sites each year. Decisions about who and what are being commemorated, and the form such commemorations should take, are also generally seen to be controlled at the national level. ${ }^{4}$ In many ways these locations are 'top-down' sites of commemoration, which have been widely considered in literature around politics and society and studies of the various events and persons who are being remembered in national spaces. ${ }^{5}$ However, less attention has generally been paid to how commemorative spaces are structured or negotiated at the local level, and our understanding of urban memorial sites may be informed by the archaeological approach of object biography. ${ }^{6}$

\footnotetext{
${ }^{1}$ Pettitt ( 2011).

${ }^{2}$ For example: Banton (no date), Farwell \& Molleson (1993), Parker Pearson (2012), Stead (1991).

${ }^{3}$ Login (2016).

${ }^{4}$ Ashplant et al. (2013). Although Winter (2014) notes that mourning extends beyond national boundaries.

${ }^{5}$ Ashplant et al. (2013).

${ }^{6}$ Briggs (1988), Gosden \& Marshall (1999), Joy (2009).
} 
This article will employ an object biographical approach to a commemorative space in the City of Kingston upon Hull, in the United Kingdom, as a means of interpreting war memorialisation in a local urban context. Object biography, as a method of inquiry, arose out of Igor Kopytoff's work on the 'cultural biography of things', in which he posited that objects have similar social lifecourses to persons, experiencing life-stages which may include: birth (that is, creation), use and reuse, movement, commodification, and decommodification, with changes to their cultural significance through these various processes. ${ }^{7}$ The potential of such an approach to material culture studies was quickly embraced by archaeologists, such as Ruth Tringham, who also saw that a biographical approach could be applied to spaces, through an exploration of the lifecycle of Neolithic houses. ${ }^{8}$ The relationships between persons and objects create rich social histories, and the meanings of both individual objects and the spaces they inhabit may be repeatedly renegotiated throughout their lifecourse. ${ }^{9}$ The commemorative space at Paragon Square, in Kingston upon Hull, is an entanglement of physical space, objects, and staged, repeated, performances, which combine to form what Tim Ingold has termed a 'taskscape' in which the relationship between space, performance, and temporality imbues social value. ${ }^{10}$ Thus an examination of the initial formation of the commemorative space and the ways in which it has been modified, elaborated upon, and socially renegotiated, offers an insight into the changing values and social relationships represented in a delimited physical space.

\section{CREATING A NEW MEMORIAL SPACE}

The city of Kingston upon Hull, located in the East Riding of Yorkshire in the North of England, has a long history as a maritime city, and it remains an important port city today. However, when the South African War (also known as, and hereafter referred to as, the Second Boer War) broke out in 1899, soldiers did not depart the city by ship but by train, from Hull's Paragon Station. For friends and relations of those who never returned, the train station became a place of significance, as the last place they may have seen their lost relatives, and as the place where their loved ones were last present in their home city. From 1847 onwards, Paragon Train Station has also been the principal point of arrival for visitors to the city of Hull and Paragon Square, the open space immediately in front of the station entrance, thus forms a focal point for arrivals and departures and is simultaneously a permanent and a transitory space.

\footnotetext{
${ }^{7}$ Kopytoff (1986).

${ }^{8}$ Tringham (1994).

${ }^{9}$ Gosden \& Marshall (1999).

${ }^{10}$ Ingold (2010).
} 
The Second Boer War (1899-1902) foreshadowed the First World War in numerous ways. The mobilisation and deployment of large numbers of volunteer soldiers from Britain and the Colonies in defence of the Empire created a sense of collective struggle in a 'Great' war. ${ }^{11}$ The conflict was more prolonged and costly than anticipated, and the deaths of combatants were framed in terms of noble sacrifice for the enterprise of Empire. Losses were significant and the dead were not repatriated to Britain or their colonial homelands, meaning that bereaved families had no gravesite to visit. Dislocated grief was given locus through the creation of war memorials within communities across Britain and in the colonies. ${ }^{12}$

The Boer War resulted in a significant shift in memorialising practices in deeply stratified British society. Prior to the Boer War, war memorials were the sole preserve of 'great' leaders and the aristocracy. ${ }^{13}$ However, with large numbers of working-class and middle-class volunteers playing a significant role in this turn-of-the-century conflict, memorialisation was extended to encompass the 'common' soldier. To commemorate the fifty-seven men who never returned to Hull after leaving to fight in South Africa, the city constructed a monumental war memorial, funded by public subscription, which would commemorate the sacrifice made by these men in perpetuity. A memorial committee was formed within the City Council, under the leadership of Sir W. Alfred Gelder, then Lord Mayor of Hull. As an architect, Gelder is likely to have taken a leading role in the decisions surrounding the memorial, although specific records of the decision-making process have not survived. A tender advertisement was posted in the Hull Daily Mail on 3 February 1903, calling for design proposals for 'a MEMORIAL of the HULL SOLDIERS who lost their lives in the South African War', which should not exceed $£ 650$ in costs over and above the costs of laying the foundations, but the paper carries no further articles relating to the subscription process or proceeding design competition. ${ }^{14}$ The monument, which was ultimately created by Leeds Marble Works, takes the form of two uniformed male figures, sculpted in white marble on a rough-hewn grey granite pedestal.

The larger-than-life figures are rendered in a dynamic pose: one figure, standing, is handed a cartridge by his wounded fellow, creating a sense of comradeship and determination, which translates from the battlefield to a sense of communal solidarity and the offering of support to the bereaved. Both sculpted figures carry bronze rifles. The white marble and gleaming bronze both catch and reflect natural light. A postcard photograph of the unveiling highlights the luminous quality of the monument,

\footnotetext{
${ }^{11}$ Arthur Conan Doyle's highly popular 1900 book, published while the war was ongoing, was entitled The Great Boer War, for example.

${ }^{12}$ Donaldson (2013).

${ }^{13}$ Donaldson (2013).

${ }^{14}$ Hull Daily Mail (1903).
} 


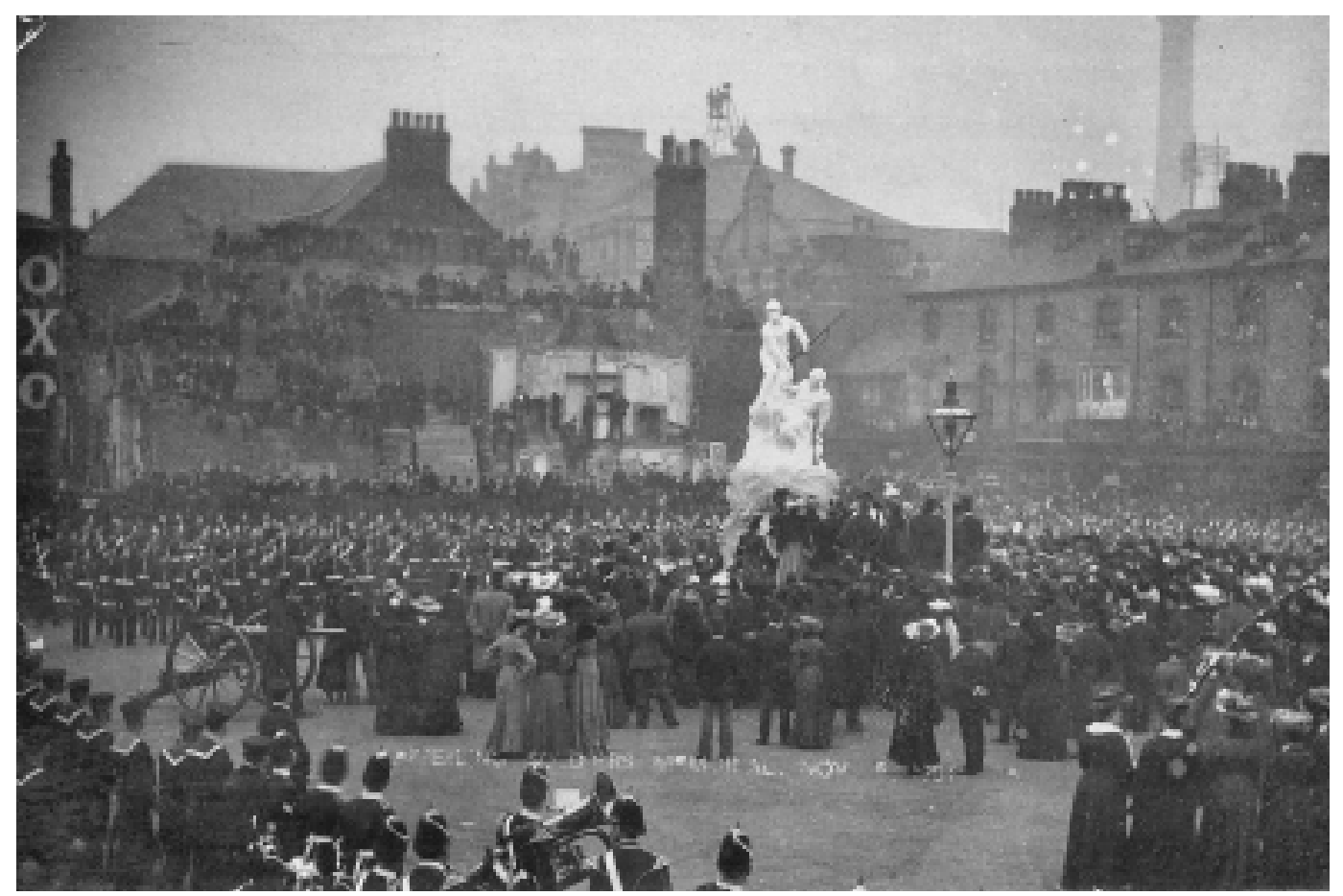

Figure 1. Unveiling of the South African War Memorial 5 November 1904. (Public domain)

in stark contrast to the dark clothing of the attendant crowd (Figure 1). The use of reflective materials is a common motif in memorial construction, which can be traced across time, culture, and religion, with examples ranging from the white quartz facing of the Neolithic chamber tomb at Newgrange in Ireland to the Taj Mahal in India, and from Sir Edwin Lutyens' Portland Stone Cenotaph at Whitehall to the whitepainted gravestones of the Srebrenica memorial in Bosnia and Herzegovina. ${ }^{15}$ The choice of a figured motif featuring soldiers clearly set the focus on the infantry soldier. This focus on the commemoration of the infantry soldier is something which has continued in subsequent war memorialisations, particularly of the First and Second World Wars, which has implications for which groups are remembered and which are overlooked or forgotten in commemorations, which will be discussed further, below. ${ }^{16}$

At 3PM on 5 November 1904, the monument, swathed in a Union Jack, was unveiled before a large public crowd, which had been waiting for hours. ${ }^{17}$ This public

\footnotetext{
${ }^{15}$ Inall (2018).

${ }^{16}$ Evans (2018).

${ }^{17}$ Hull Daily Mail (2006).
} 
ceremony was led by Colonel A. J. M. Wright (standing in for Major General Leslie Rundle, who was unable to attend), Alderman W. M. Jarman, and the Lord Mayor Sir W. Alfred Gelder. The act of commemoration was itself something to be commemorated, as inscribed on a stone escutcheon at the base of the plinth. The names of Jarman and Gelder were thus declared in perpetuity, signalling the role that the local government played in curating the memory of the dead, who were themselves represented in the monument as an unnamed collective. Interestingly, neither Rundle (who had meant to be present) nor Wright were included in the inscription as representatives of the military. The funding of the monument by public subscription was boldly stated on the monument, highlighting the depth of feeling and generosity of the citizen body. This ceremonial event established the site as a commemorative space and laid the foundations, literally and figuratively, for the memorialisation of subsequent conflicts.

\section{LAYERING COMMEMORATION}

Within a decade of the dedication of Kingston upon Hull's monument to the fallen of the South African War, Britain was once again embroiled in another 'Great War': this time the 'War to End all Wars'. The First World War (1914-18) resulted in casualties on an unprecedented scale. The magnitude of loss was such that Victorian mourning rituals were permanently disrupted. ${ }^{18}$ As in the Second Boer War which had preceded it, a decision was taken not to repatriate the bodies of fallen soldiers, and the remains of a large number of casualties were never formally identified. While the Imperial War Graves Commission (IWGC, now the Commonwealth War Graves Commission (CWGC)) oversaw the creation of extensive war cemeteries, their location in foreign fields rendered graveside visitations impossible for the majority of the British population so that, once again, the bereaved were deprived of graves to visit. Such was the interest in the memorialisation in these far-flung cemeteries that the Imperial War Museum staged an exhibition in 1925 to give citizens an opportunity to view images of over a thousand memorials as well as architectural and sculptural models, which would give the bereaved a flavour of how their lost loved ones were being memorialised and cared for in these distant fields. ${ }^{19}$ The Royal Academy and a range of other artistic bodies offered extensive advice to memorial committees on the proper aesthetics for town and country memorials. ${ }^{20}$ War memorials proliferated, and the UK

\footnotetext{
${ }^{18}$ Whitmore (2017).

${ }^{19}$ The Times (1925).

${ }^{20}$ King (1998).
} 
National Inventory of War Memorials estimated some 5,151 had been officially unveiled by $1920 .{ }^{21}$

The erection of a large memorial in Hull to commemorate the fallen of the First World War was first proposed in 1918 by ex-servicemen. The monument was funded by public subscription, and the funds raised in Hull by the Great War Trust (which also provided support for disabled veterans and the dependent children of the dead) were substantial. ${ }^{22}$ The funding of war memorials by public subscription had become widespread practice following the Boer War and this tradition continued in the aftermath of the First World War. It was reported in the Hull Daily Mail on 10 January 1923 that, after considering a number of sites, Paragon Square had been chosen as the appropriate location by an executive committee presided over by Lord Mayor Charles Paine. ${ }^{23}$ A design by the Scottish architect T. Harold Hughes was selected from forty-four submitted designs, which were assessed by a representative of the Royal Institute of British Architects. It was reported that the proposed design of the Cenotaph would be 'simple and dignified in character and scheme' and would 'embrace the present South African War Memorial'. ${ }^{24}$

The Cenotaph construction contract was awarded to Quibell and Son, a local construction firm, which had previously built some of Hull's prominent buildings. A foundation stone was laid for the Cenotaph at Paragon Square on 8 November 1923 accompanied by a religious service. Similar to the unveiling of the Boer War Memorial, the laying of the foundations was accompanied by an inscription, which named the dignitary responsible for its establishment: Charles Raine Jnr, Lord Mayor of Hull, once again underscoring the centrality of the local administration as the architects of commemoration.

The Cenotaph design was heavily influenced by that of Lutyens' Cenotaph at Whitehall in London. A temporary structure had been erected in Whitehall for a victory parade in 1919, which was later replaced by a permanent Cenotaph that was unveiled on Armistice Day 1920. The Whitehall Cenotaph was popularly received as a national monument: Lutyens' simple, elegant design was 'a form on which anyone could ascribe his or her own thoughts, reveries, sadnesses ${ }^{25}$ and it was broadly imitated and referenced in a number of First World War Memorials erected during the 1920s, including those in Leeds, Glasgow, and Stoke-on-Trent. ${ }^{26}$ The Cenotaph in Hull was unveiled on 20 September 1924. In echoing the design of the national monument,

\footnotetext{
${ }^{21}$ Winter (2014: 257).

${ }^{22}$ King (1998).

${ }^{23}$ Hull Daily Mail (1923a).

${ }^{24}$ Hull Daily Mail (1923b).

${ }^{25}$ Winter (2014: 104).

${ }^{26}$ King (1998: 140-50).
} 
Hughes created an implicit link between the local and the national commemorations, fostering a local sense of national unity. While Lutyens' monument was dedicated simply to 'THE GLORIOUS DEAD', the inscription on the Hull Cenotaph read:

\author{
ERECTED IN THE MEMORY \\ OF THE MEN OF \\ KINGSTON-UPON-HULL \\ WHO \\ LAID DOWN THEIR LIVES \\ FOR THEIR COUNTRY \\ IN \\ THE GREAT WAR \\ 1914-1918
}

While the monument in London spoke to the grief of an Empire, Hull's memorial emphasised the cost of the Great War in its local context.

The Hull Cenotaph is a more elaborate monument than Lutyens' simple structure, featuring two low, flanking, walls which effectively enclose the space, and a raised platform which both elevates the Cenotaph and physically 'embraces' the Boer War memorial, as described in reports at the time. The monument also includes an altar, which acts as a focal point for commemorative activities, most particularly the laying of wreaths. The space between the two memorials was an open grassed area with plantings of blooming plants, accompanied by a small, dedicatory plaque indicating that 'the women of the three ridings of Yorkshire' were responsible for the contribution of a memorial garden to a site that was now re-established as a complex of memorials.

To coincide with the unveiling of the Cenotaph, substantial modifications were made to the existing Boer War Memorial. The sculpted memorial had been physically supplanted by the new Cenotaph (it was moved approximately 35ft (approx. 10.6 m) to the north) so that the Cenotaph could be sited on the spot which had previously accommodated the Boer War memorial. ${ }^{27}$ Its rough-hewn plinth was also partially replaced with a new plinth in keeping with the architectural style of the Cenotaph. The modification resulted in a reduction of the overall height of the Boer War Memorial. These acts of physical displacement and alteration simultaneously linked and legitimised the memorialisation of the First World War with that of the Boer War in the same commemorative space. However, they also had the effect of subordinating the existing memorial to the new, larger, monument dedicated to the fallen of a conflict which had been more devastating to the community, and the Empire, and which was in more recent memory.

${ }^{27}$ Hull Daily Mail (1923a). 
The dedicatory escutcheon of the Boer War memorial was also removed, being replaced with a bronze plaque, replicating the original inscription. In contrast to the democratic, and yet anonymous, unity previously afforded the fallen, the names of the Boer War dead were also inscribed in newly mounted bronze plaques fixed on three sides of the plinth. They are laid out by order of cause of death: those who were 'Killed in Action', who 'Died of Wounds', and those who 'Died of Disease Etc.', thereby creating a hierarchy of sacrifice. Within each category the names were ordered first by rank and then by alphabetical order. In this way, the existing social order was replicated within the monument. The naming of the dead effectively closed the monument, fixing it in the past and shifted the focus of contemporary commemoration to the new monument, which offered a new democratic anonymity to the recent war dead.

The interwar years were a period of intensive commemoration in Britain, and Armistice Day observances (held on 11 November) were prominent in the national calendar. In cities, towns, and villages locals remembered their war dead with parades and religious services, and in Hull the Cenotaph became the locus for these activities.

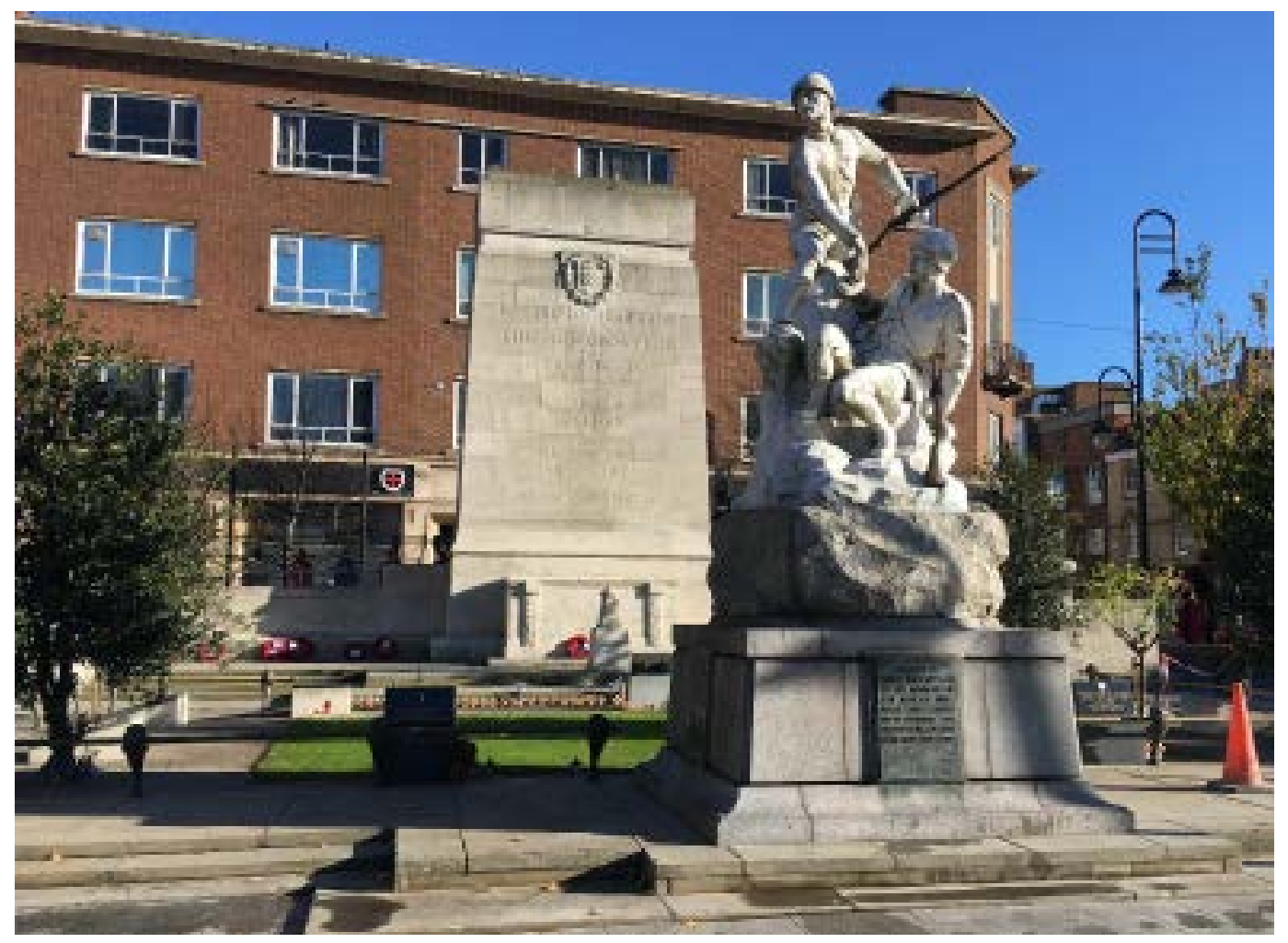

Figure 2. Paragon Square as it appeared on 11 November 2017. (Photography by the author) 
While the Cenotaph was the central focus for annual commemorations, and at this principal site the representation of the war dead at the Cenotaph took the form of a democratised and anonymous collective, the dead were named and commemorated in other memorials around the city of Hull, and at wider locations across the region of Eastern Yorkshire. The UK National Inventory of War Memorials recorded 1,232 First World War Memorials in the Humberside region, which encompasses Hull. ${ }^{28}$ Many churches and workplaces erected street shrines naming the men who had been resident in the parish, or who had been employees of the erecting company, who had gone to war. Many of the monuments were set up during the war (a practice noted across Britain), listing all who served, updating the list to indicate those who would not return. ${ }^{29}$ The majority of these memorials were constructed of wood and fell into disrepair during the interwar years, and their fates are largely unknown. However, a few such memorials survive and several restored examples are on permanent display in Hull's Streetlife Museum.

Following the outbreak of the Second World War, public observances of Armistice Day were suspended, partly due to the incongruity of commemorating peace in a time of war, and, of course, having large concentrations of people in a single location was inadvisable given the context. At the conclusion of the War in Europe in June 1945, Britain was faced with the challenge of commemorating this most recent conflict alongside the First World War, which was still within living memory for a significant proportion of the population. With a commemorative framework established following the Boer War, which had been consolidated in the wake of the First World War, the Second World War was folded into the existing tradition, albeit with the emphasis shifted from Armistice Day (11 November) to the nearest Sunday, which was already being referred to as 'Remembrance Sunday' ${ }^{30}$ Monumental commemoration was literally etched into the existing narrative through the addition of new inscriptions to extant war memorials, embracing the fallen of this latest conflict. The words

\section{AND \\ WORLD WAR \\ 1939-1945 \\ THEIR NAME LIVETH FOR EVERMORE}

were added to the inscription on the Cenotaph in Hull in 1946: unveiled by the Lord Mayor, Isaac Robinson, on Remembrance Sunday, with an associated parade reported in the Hull Daily Mail to have included surviving veterans of the Boer War, First

\footnotetext{
${ }^{28}$ Gregory (2014).

${ }^{29}$ Moriarty (1997).

${ }^{30}$ Gregory (2014).
} 
World War, and Second World War. ${ }^{31}$ The epigraphic style of the inscription is consistent with the original inscription, creating a coherent whole, inextricably linking the two conflicts in the physical monument. The Remembrance Sunday parade of 1946, consisting of veterans of all three wars now memorialised in the commemorative space served to consolidate and legitimise remembrance of the most recent conflict into the established performative rituals of commemoration enacted at the site.

The next major conflict in which British forces became actively involved was the Korean War (1950-3), and it too is memorialised in Paragon Square. However, details regarding its installation are obscure. There were no Hull casualties recorded during the conflict. The low-key memorial, a $75 \mathrm{~cm} \times 60 \mathrm{~cm}$ slab of dark grey granite on a Portland stone plinth, is simply inscribed 'KOREAN WAR/ 1950-53'. The majority of the polished stone face is blank, suggesting that space was left to record the names of casualties that never eventuated. The monument stands out as an odd addition to Paragon Square. However, it is representative of the way in which the Korean War was immediately incorporated into wider war commemorations in Britain. On 9 November 1950 The Times reported that an area of the Field of Remembrance adjacent to Westminster Abbey in London had been 'set apart to commemorate the fallen of the war in Korea'. ${ }^{32}$ However, despite this ready acceptance of the conflict into commemorative performance in Britain, the low number of casualties $(1,078)$ led the Korean War to become something of a forgotten conflict, largely absent from the British narrative of remembering wars of the 20th century. ${ }^{33}$ The understated form of memorialisation also set the tone for the commemoration of later conflicts, none of which are commemorated with large-scale monuments.

The First World War continued to be memorialised even as it faded into memory, and the Second World War was subsumed into existing commemorative practices. In 1956 a new monument was inserted into the memorial gardens at Paragon Square, commemorating the Battle of Oppy Wood. The Battle of Oppy Wood was fought on 3 and 4 May 1917 in the Pas-de-Calais, Northern France, as part of the larger Battle of Arras. The battle was fierce and resulted in significant casualties for the East Yorkshire Regiment. ${ }^{34}$ These losses have been commemorated at Oppy, France; in the village of Cottingham on the outskirts of Hull; and in Paragon Square. The 1956 memorial took the form of a gift of a replica of one of the marker posts that signified

\footnotetext{
${ }^{31}$ Humber (1946), Hull Daily Mail (1946b).

${ }^{32}$ The Times (1950). Fields of Remembrance are a common feature of commemorative activities associated with Remembrance Sunday in Britain, in which discrete grass areas, often in close proximity to a war memorial, are open for members of the public to leave a tribute in the form of a small wooden cross adorned with an artificial red poppy.

${ }^{33}$ Hennessey (2015).

${ }^{34}$ Bilton (2015).
} 
the extent of German advance at the battle site. The replica signifies the ongoing commemorative relationship between the city of Hull and the village of Oppy, France.

From the 1950s until the 1990s there was a long period in which the commemorative space at Paragon Square went unaltered. New conflicts were not commemorated in the area: broadly typical of a lack of commemoration of more recent or ongoing conflicts in Britain during the latter half of the 20th century. ${ }^{35}$ War commemorations faded toward irrelevance and the associated war memorials faded into the background of daily life, largely invisible in plain sight, and by the end of the century Paragon Square was predominantly being used as a parking lot. ${ }^{36}$

\section{BIOGRAPHIES AND RENEGOTIATIONS OF MEMORY}

Communication is key to the creation of collective memory and the monuments of Paragon Square have an important role to play in the formation of local memories around the two World Wars, military service, and sacrifice. The Boer War Memorial, as the establishing monument of the site, places a strong emphasis on the role of the soldier through its sculptural motif, and it is explicitly focussed on the fallen. The overt relationship between the Boer War Memorial and the Cenotaph tacitly transfers the infantry focus to the new monument, which is also unambiguously dedicated to the memory of the infantry casualties of the two World Wars. A consequence of these foci is the contrasting lack of communication about survivors of conflicts, and those who were not members of infantry units.

During the 1990s Britain experienced a renewed interest in war memorialisation. This reinvigoration was stimulated by several factors: the fiftieth anniversary of the Second World War; the rapidly dwindling number of survivors of the First World War; and Britain's involvement in renewed international conflict in the First Gulf War and peacekeeping operations in the Balkans. ${ }^{37}$ In this context, the focus and flavour of commemoration also shifted. Many of the memorials erected in Paragon Square from this time onwards provide representation for groups who felt they had been overlooked in public commemorations of the two World Wars and subsequent conflicts.

One of the largest groups who had largely been absent in war commemorations is veterans. Veterans who may have returned from service damaged or disabled had long been disregarded in favour of commemoration of the fallen. The lack of recognition of and public support for surviving veterans has been a matter of concern dating back

\footnotetext{
${ }^{35}$ Ashplant et al. (2013).

${ }^{36}$ Winter (1999), Young (2001).

${ }^{37}$ Winter (2006).
} 
at least to the commemoration of the First World War. Numerous newspaper articles published around Armistice Day exhorted people to remember disabled ex-servicemen, and the Poppy Appeal under the auspices of Lord Haig presented a means through which the populace could offer charitable support for veterans as part of their commemorative activities. ${ }^{38}$ It became common practice to place wreaths made of artificial poppies as offerings at memorials on Remembrance Sundays and other key commemorative dates. Through this process, both veterans and the fallen are remembered: the fallen commemorated in the permanent monument, and the survivors implicit in the impermanent floral tributes.

However, memorials erected in Paragon Square from the 1990s are more explicit in their commemoration of veterans. Three memorials commemorating the contributions of specific units or campaigns of the Second World War were installed during this time, and all offer varying degrees of recognition for veterans. The specific dates of their installation are uncertain; however, their similarity of style and manufacture, and close physical proximity suggest that they were likely installed within a short space of time, if not contemporaneously. ${ }^{39}$ These monuments commemorate those who served in the Normandy Campaign of 1944, Arctic Convoy Veterans who served between 1941 and 1945, and members of the Eighth Army who also served between 1941 and 1945. None of the inscriptions on these monuments uses the term 'fallen', and the Arctic Convoy memorial is most explicit that it is veterans who are being commemorated in the monument.

The Normandy Veterans Association was responsible for the installation of a memorial to the Normandy campaign. The Association disbanded in 2014 and its final recorded commemoration at the Cenotaph was the preceding year on 6 June 2013..$^{40}$ The inscription on the monument reads:

\author{
REMEMBERING ALL THOSE WHO \\ SERVED IN THE NORMANDY CAMPAIGN \\ JUNE $6^{\mathrm{TH}}-$ AUGUST $20^{\mathrm{TH}} 1944$ \\ LEST WE FORGET \\ HULL BRANCH \\ NORMANDY VETERANS ASSOCIATION
}

thereby recognising the contribution of all service personnel, while the words 'lest we forget' offer tacit recognition of casualties.

\footnotetext{
${ }^{38}$ Gregory (2014).

${ }^{39}$ Requests have been submitted to Hull City Council and the local branch of the British Legion seeking further information about the establishment of the memorials discussed in this article. No responses have been received at the time of publication.

${ }^{40}$ Hull Daily Mail (2013).
} 
The Eighth Army was drawn from the Western Desert Force in 1941, which, during the Second World War, saw service predominantly in North Africa and was famously referred to as the 'Desert Rats'. Following the War, a Veterans Association was founded, which had over thirty branches, including an East Yorkshire branch. The Veterans Association officially disbanded in 2002 and the last six surviving members of the East Yorkshire Branch held their final commemorative service in 2010, not at the Cenotaph, but rather at St Mary's Church, Sculcoates Lane in North Hull. ${ }^{41}$

The Russian Convoy Club oversaw the installation of the memorial to Artic Convoy Veterans. The Arctic Convoys, initiated by Winston Churchill, ran between 1941 and 1945, transporting supplies from the West to Russia, facing dangers presented by German U-boats, surface vessels, and the Luftwaffe, in addition to the perils of the sea and weather. ${ }^{42}$ Primarily consisting of Merchant Navy vessels, accompanied by Royal Navy escorts, the convoys were ripe targets, and the allies exploited this appeal, using the convoys as a tactical lure as part of a strategy aimed at weakening German forces. ${ }^{43}$ The contributions of merchant mariners to the war effort have largely been overlooked, and there are relatively few memorials dedicated to their service in Britain. ${ }^{44}$ Veterans of the Arctic Convoys were not offered campaign medals until 2013, more than seventy years after the first convoys made their perilous run across the North Sea. ${ }^{45}$

The path to memorialisation was not generally swift or smooth. One of the more protracted examples was the commemoration of four Hull men who were recipients of the Victoria Cross (VC). The VC is Britain's highest military honour, but negotiations with Hull City Council seeking permission for a memorial were drawn out for over a decade, between 1989 and 1999. News reports indicate that the memorial, a grey granite slab on a Portland stone plinth, had been installed by Remembrance Sunday $1999 .{ }^{46}$ A service of dedication was held on 16 April the following year, which included a religious sermon by Canon John Waller of Hull's Holy Trinity Church, attended by the Lord Mayor, Brian Wilkinson, and Frank Nunez, the President of the Hull branch of the Royal British Legion, as well as family members of the Victoria Cross recipients. ${ }^{47}$ The memorial also is one of the few on the site that commemorates named individuals:

\footnotetext{
${ }^{41}$ Jenna Thompson (2010).

${ }^{42}$ Levy (2003).

${ }^{43}$ Lambert (1996).

${ }^{44}$ Evans (2018).

${ }^{45}$ Royal Navy (2013).

${ }^{46}$ Ritchie (2000).

${ }^{47}$ Sutton (2000).
} 


\author{
FOR VALOUR \\ THIS IS TO COMMEMORATE \\ THE GALLANTRY OF THE MEN OF \\ KINGSTON UPON HULL \\ PRIVATE JOHN CUNNINGHAM VC \\ 2ND LIEUTENANT JOHN HARRISON VC MC \\ BOATSWAIN JOHN SHEPPARD VC CGM \\ SERGEANT WILLIAM BERNARD TRAYNOR VC \\ WHO \\ FOR THEIR HEROIC DEEDS \\ IN TIME OF WAR \\ WERE AWARDED \\ THE \\ VICTORIA CROSS \\ TO THEM WE OWE A DEBT OF HONOUR
}

Two of the recipients, John Harrison and John Cunningham, were awarded the honour for their service during the First World War. John 'Jack' Harrison was killed in action during the Battle of Oppy Wood, ${ }^{48}$ while John 'Jack' Cunningham (who was awarded his VC for service in the Battle of Ancre) survived the war. Similarly, John Sheppard and William Traynor also both returned home as veterans. ${ }^{49}$ Thereby the memorial also commemorates both casualties and veterans. John Sheppard was the fourth person ever awarded a VC, for service in the Crimean War. His commemoration on the VC monument is the only recognition of the Crimean War in Paragon Square. However, as the monument does not include any information about the conflicts or circumstances for which the awards were given, neither the Crimean conflict nor the veteran status of three of the four recipients are explicitly recognised or communicated to persons engaging with the monument.

Formal recognition of casualties of war from post-Second World War conflicts also came in the 1990s, when an inscription was added to the altar space on the Cenotaph. ${ }^{50}$ The inscription, again maintaining the epigraphic style of the preceding inscriptions reads:

\author{
AND IN \\ MEMORY OF THOSE \\ WHO GAVE THEIR LIVES IN LATER \\ CONFLICTS
}

\footnotetext{
${ }^{48}$ Jack Harrison is thus commemorated three times in Paragon Square: in the Cenotaph commemorating the fallen of the First World War, in the Oppy Wood memorial post, and in the VC memorial.

${ }^{49}$ Smith (2008).

${ }^{50}$ According to the Imperial War Museum inventory of war memorials (Memorial No. 35180), the additional inscription was unveiled on 20 June 1993, although it has not been possible to confirm this date.
} 
This alteration was clearly intended as an all-encompassing recognition of military sacrifices made by the citizens of Hull. However, as discussed below, the addition of two plaques to the monument and a rededication in 2013 indicate that twenty years after the 1993 inscription, it was deemed inadequate by at least some, influential, members of the community.

Two memorials were unveiled on 27 October 2008. The memorials were the first to be installed following substantial conservation works undertaken in 2007 (discussed below), which also prescribed the permitted form which new memorials could take. As with other monuments added to the site since the latter half of the 20th century, these new installations offered recognition to groups whose service was felt to have been overlooked. The first of these memorials was at the behest of the Burma Star Association, whose proposal to install a memorial at Paragon Square appears to have precipitated the 2007 conservation works. ${ }^{51}$

The Burma Star Association, which currently has forty-two branches in the United Kingdom, represents veterans of the Burma campaign of the Second World War, along with the surviving family members of casualties. ${ }^{52}$ The Fourteenth Army, the largest force the Commonwealth had ever enlisted, was frequently referred to as the 'Forgotten Army' and there is a strong sense that their contributions to the war effort have been neglected in favour of a focus on the conflict in Europe. ${ }^{53}$ While the Burma Star Association is primarily focussed on the needs of veterans, interestingly, the monument unveiled at Paragon Square is focussed exclusively on the fallen:

\author{
IN MEMORY OF \\ FALLEN COMRADES \\ WHO SERVED IN BURMA \\ AND THE FAR EAST \\ IN WORLD WAR TWO
}

The Royal Naval Association memorial, which was unveiled on the same day, also explicitly commemorates the fallen, but is inclusive of all conflicts since the First World War:

\author{
THE ROYAL NAVAL ASSOCIATION \\ HULL BRANCH \\ 'Once Navy Always Navy' \\ In remembrance of all Royal Naval Personnel \\ who gave the ultimate sacrifice \\ in the two great wars
}

\footnotetext{
${ }^{51}$ Hampel (2007).

${ }^{52}$ Burma Star Association (no date).

${ }^{53}$ Julian Thompson (2010).
} 
and all subsequent conflicts.

'In defence, and for freedom'

In 2010 another new memorial was unveiled at Paragon Square, this time specifically commemorating fallen Royal Marines. The memorial was privately funded by servicemen and their families under the auspices of the Hull Royal Marines Association, in accordance with the funding guidelines laid out in the Conservation Plan. The design of the monument was also in keeping with the Plan's directions, that is: a light grey granite stone on a Portland stone plinth. News coverage of the dedication makes it clear that the commemorative focus of the memorial was marines who had died in service in the ongoing conflicts in Afghanistan and Iraq. ${ }^{54}$ However, the inscription explicitly links the monument to the First and Second World Wars:

\author{
BY SEA BY LAND \\ ROYAL MARINES ASSOCIATION \\ IN MEMORY OF \\ FALLEN COMRADES \\ TWO WORLD WARS \\ AND GLOBAL CONFLICTS \\ IN PERPETUITY
}

chaining these earlier conflicts to contemporary ones. The connection was reinforced at the unveiling through the participation of the oldest surviving member of the Marines Association, then aged 95, who laid the first wreath. ${ }^{55}$ Thus the significance of contemporary sacrifice is embedded in the existing narrative of war commemoration, highlighting the specific role played by the Royal Marines, who felt their contributions had been overlooked.

A year after the unveiling of the Royal Marines memorial a monument was unveiled representing the Royal Air Force (RAF). Firmly in keeping with the permitted memorial form, the monument is a grey granite slab on a Portland stone plinth, bearing a white inscription, which reads:

\author{
IN REMEMBRANCE OF \\ ALL WHO SERVED IN \\ THE ROYAL AIR FORCE \\ Proudly and thankfully \\ we will remember them \\ ROYAL AIR FORCES ASSOCIATION \\ Kingston upon Hull Branch \\ Sept. 2011
}

\footnotetext{
${ }^{54}$ Hull Daily Mail (2010).

${ }^{55}$ Kuria (2010).
} 
Interestingly, this is the first monument, since the Cenotaph, to include information about the date of dedication in the inscription.

Undoubtedly, the First and particularly the Second World Wars predominate in the narratives of memorialisation represented in the layers of memorialisation visible in Paragon Square. Just as significant are the conflicts which are entirely absent from the memorial space. No monument explicitly commemorates either the Falklands or Northern Irish conflicts. Nor is Britain's involvement in the First Gulf War or Balkan peacekeeping operations acknowledged. The silence on these conflicts is not surprising, as each of these conflicts was slow to be recognised in national commemorations. For example, the 1982 Falklands conflict was not officially included in Remembrance Sunday commemorations in London until $1998 .{ }^{56}$ In this way, commemorations at Paragon Square reflect the wider, national narratives around which conflicts should be firmly embedded in collective memory, and which are being allowed to fade into the background.

Other groups also remain invisible or under-represented in the complex of memorials at Paragon Square. Women in particular have been poorly represented. The Cenotaph inscriptions to the First and Second World Wars explicitly state that they commemorate the 'men' of Hull who died in those conflicts. A small bronze plaque is embedded within the memorial garden of Paragon Square bears the inscription:

\section{MAY THESE BLOSSOMS FLOURISH \\ FOR THE WOMEN OF \\ THE THREE RIDINGS OF YORKSHIRE \\ WHO WILL FOREVER REMEMBER}

The text of the inscription indicates that the plaque is to be associated with the foundation of the memorial garden in conjunction with the installation of the Cenotaph in the 1920s. The women here referred to are a collective, subsuming all differences in regional identity and are represented as curators of memory. The horticultural tribute is also a form of memorial that would have been seen as an appropriately female contribution in the 1920s.

It was not until 2011 that the role of women performing active service was acknowledged within the commemorative space, and, even then, this was not done explicitly. The RAF memorial's text commemorating 'all who served' can be read to implicitly include female service personnel who had served in the RAF specifically, although it is not clear that it was intended for the monument to be read in this way.

${ }^{56}$ Evans (1998). 
When the memorial was rededicated in 2013 a bronze plaque was added to the right pedestal which bears the inscription:

\author{
REDEDICATED \\ 2013 \\ IN MEMORY OF \\ THE PEOPLE \\ $\mathrm{OF}$ \\ KINGSTON UPON HULL \\ WHO HAVE SERVED \\ FOUGHT AND DIED FOR \\ THEIR COUNTRY \\ SINCE 1945
}

Women are thus encompassed in this addition to the layered commemoration, yet their contributions and sacrifices remain muted in what remains a predominantly masculine memorial.

Civilian casualties are also entirely absent from Paragon Square. This is despite proximity of bombing during the blitz, which heavily damaged Hammond's department store adjacent to the Square. A suggestion was made that the damage to Hull caused by the blitz and the civilian cost of the First and Second World Wars be commemorated through the addition of a plaque to the Cenotaph in a letter to the Hull Daily Mail in $1946 .{ }^{57}$ The suggestion was never taken up, although civilian victims have been memorialised elsewhere in Hull (through a monument to victims of the Blitz in Hull's Northern Cemetery, and a plaque commemorating the victims of the bombing of the Prudential Building at that site in Victoria Square). There remained a strong desire within the community for the erection of a Hull People's Memorial, dedicated to civilian victims of both World Wars, to be located in city centre. ${ }^{58}$ The memorial (funded via charitable donations) was granted planning permission in 2016 and unveiled on 12 May 2018, ${ }^{59}$ sited in Paragon Street, in close proximity to the Square, thereby forming a satellite memorial to the Paragon Square commemorative space. ${ }^{60}$

\footnotetext{
${ }^{57}$ Hull Daily Mail (1946a).

${ }^{58}$ Hull People's Memorial (no date).

${ }^{59}$ Hull Daily Mail (2011).

${ }^{60}$ Campbell (2016).
} 
Table 1. List of memorials located in Paragon Square, Kingston upon Hull, United Kingdom.

\begin{tabular}{|c|c|c|c|}
\hline War or conflict & Memorial form & Group memorialised & Date of unveiling \\
\hline Second Boer War & $\begin{array}{l}\text { White marble sculpture } \\
\text { on granite plinth }\end{array}$ & $\begin{array}{l}\text { Men of Hull who died in the } \\
\text { South African War }\end{array}$ & 5 November 1904 \\
\hline First World War & $\begin{array}{l}\text { Cenotaph constructed of } \\
\text { Portland stone }\end{array}$ & $\begin{array}{l}\text { Men of Hull and local officials } \\
\text { who died in the Great War }\end{array}$ & 20 September 1924 \\
\hline First World War & $\begin{array}{l}\text { Memorial garden with } \\
\text { small, dedicatory bronze } \\
\text { plaque on granite plinth }\end{array}$ & $\begin{array}{l}\text { Men of Hull and local officials } \\
\text { who died in the Great War } \\
\text { and the women of Yorkshire } \\
\text { as a bereaved collective }\end{array}$ & $\begin{array}{l}1924 \text { no specific } \\
\text { unveiling recorded }\end{array}$ \\
\hline Second World War & $\begin{array}{l}\text { Additional inscription to } \\
\text { existing Cenotaph }\end{array}$ & $\begin{array}{l}\text { Men of Hull who died in the } \\
\text { Second World War }\end{array}$ & 10 November 1946 \\
\hline First World War & Stone replica marker post & $\begin{array}{l}\text { Fallen of the Battle of } \\
\text { Oppy Wood, France }\end{array}$ & Easter 1956 \\
\hline Korean War & $\begin{array}{l}\text { Dark grey granite slab on } \\
\text { Portland stone plinth }\end{array}$ & $\begin{array}{l}\text { No specific casualties. } \\
\text { Korea conflict as a whole }\end{array}$ & unknown \\
\hline $\begin{array}{l}\text { Post-Second World } \\
\text { War conflicts }\end{array}$ & $\begin{array}{l}\text { Inscription added to } \\
\text { Cenotaph altar }\end{array}$ & $\begin{array}{l}\text { All who lost their lives in } \\
\text { post-Second World War } \\
\text { conflicts }\end{array}$ & c. 1993 \\
\hline $\begin{array}{l}\text { Crimean War, } \\
\text { Second Boer War } \\
\text { and } \\
\text { First World War }\end{array}$ & $\begin{array}{l}\text { Dark grey granite slab } \\
\text { on Portland stone plinth }\end{array}$ & $\begin{array}{l}\text { Victoria Cross recipients who } \\
\text { were from the Hull area }\end{array}$ & c.1999 \\
\hline Second World War & $\begin{array}{l}\text { Vertical black granite slab } \\
\text { on grey granite plinth }\end{array}$ & $\begin{array}{l}\text { Russian Convoy Club, } \\
\text { Artic Convoy veterans }\end{array}$ & pre-2007 \\
\hline Second World War & $\begin{array}{l}\text { Vertical black granite slab } \\
\text { on grey granite plinth }\end{array}$ & $\begin{array}{l}\text { All who served at Normandy, } \\
\text { Normandy Veterans } \\
\text { Association }\end{array}$ & pre-2007 \\
\hline Second World War & $\begin{array}{l}\text { Vertical black granite slab } \\
\text { on grey granite plinth }\end{array}$ & $\begin{array}{l}\text { All who served in the Eighth } \\
\text { Army in North Africa, Sicily, } \\
\text { and Austria, 1941-5 }\end{array}$ & pre 2007 \\
\hline $\begin{array}{l}\text { First and Second } \\
\text { World Wars and } \\
\text { 'all subsequent } \\
\text { conflicts' }\end{array}$ & $\begin{array}{l}\text { Dark grey granite slab on } \\
\text { Portland stone plinth }\end{array}$ & $\begin{array}{l}\text { All Royal Naval personnel who } \\
\text { died in service since the } \\
\text { First World War }\end{array}$ & 27 October 2008 \\
\hline Second World War & $\begin{array}{l}\text { Grey granite slab on } \\
\text { Portland Stone plinth }\end{array}$ & $\begin{array}{l}\text { Fallen comrades of Burma } \\
\text { and Far East campaigns }\end{array}$ & 27 October 2008 \\
\hline $\begin{array}{l}\text { First and Second } \\
\text { World Wars and } \\
\text { 'global conflicts in } \\
\text { perpetuity' }\end{array}$ & $\begin{array}{l}\text { Grey granite slab on } \\
\text { Portland Stone plinth }\end{array}$ & $\begin{array}{l}\text { Royal Marines who have } \\
\text { fallen since the First World } \\
\text { War and all who may fall in } \\
\text { future conflicts }\end{array}$ & 22 September 2010 \\
\hline
\end{tabular}


Table 1. Continued.

\begin{tabular}{|c|c|c|c|}
\hline War or conflict & Memorial form & Group memorialised & Date of unveiling \\
\hline $\begin{array}{l}\text { No specific conflict } \\
\text { named }\end{array}$ & $\begin{array}{l}\text { Grey granite slab on } \\
\text { Portland Stone plinth }\end{array}$ & $\begin{array}{l}\text { All who served in the } \\
\text { Royal Air Force }\end{array}$ & 18 September 2011 \\
\hline $\begin{array}{l}\text { Post-Second } \\
\text { World War }\end{array}$ & $\begin{array}{l}\text { Bronze plaques added to } \\
\text { Cenotaph flanking walls }\end{array}$ & $\begin{array}{l}\text { 'People of Hull who have } \\
\text { served, fought and died for } \\
\text { their country since } 1945 \text { ' }\end{array}$ & 2013 \\
\hline
\end{tabular}

\section{LEGITIMATION AND CONTROL OF MEMORY}

It is clear that veterans associations are key drivers behind the installation of new monuments in Paragon Square. Monuments commemorating conflicts since the 1990s have also been advocated by surviving family members. The military connections of these groups offer them a degree of influence and, most importantly, legitimacy. This can be contrasted with the push by campaigners for a memorial to civilian victims of the two World Wars, who campaigned long and hard for permission to construct a memorial, but which remains excluded from the main Paragon Square commemorative site.

The memorials which have been erected in the Square, through their very presence in the recognised commemorative space, legitimate the commemoration of the memorialised groups. Particularly, they legitimise the remembering of non-infantry combatants whose role in the First and Second World Wars had been largely subsumed by a narrative focus on the soldier, which had been firmly established in the very foundation of the commemorative space following the Second Boer War. The layering of memorials, creating a palimpsest of discreet groups (marines, air force, VCs etc.) form lieux de mémoire which underscore not only their presence in the conflicts being commemorated, but also their prolonged sense of absence or forgetting in the collective commemorations of the city. ${ }^{61}$

The seemingly rapid and uncontrolled addition of multiple monuments during the 1990s appears to have created some tensions within the local administrative framework. In 2007 Hull City Council proposed a new Conservation Plan for the Memorial Garden between the Cenotaph and the Boer War Memorial. The proposal included resiting of several of the memorials. One of the stated reasons for the rearrangement of memorials within the space was 'the uncontrolled installation of several assorted memorials in recent years ...' which 'undermined' the 'simplicity and symmetry' of the commemorative space. ${ }^{62}$ As early as 1918, 'simplicity' was recognised as an important design principle in the creation of war memorials as a means of conveying

\footnotetext{
${ }^{61}$ Nora (1989).

${ }^{62}$ Hampel (2007).
} 
an air of sincerity ${ }^{63}$ It is clear in Hempel's conservation assessment in 2007 that a sense of simplicity remained an important organising principle, for the continuing maintenance of the commemorative space, which by this time was composed of eight separate physical monuments. Hempel's assessment portrayed a sense that management of the composite site had escaped administrative control, which should be meaningfully re-established. Strict guidelines were set out for the arrangement of the space, including a cap on the number of new memorials which could be permitted and restrictions on the size, design, construction materials, and positioning of new memorials being considered for addition to the site.

Through these regulations, Hull City Council firmly re-established control of the physical memorialisation of war dead in Paragon Square. However, in doing so the Council also impacted upon the capacity for new conflicts and their attendant losses to be memorialised. At a time when Britain was engaged in ongoing conflicts in Afghanistan and Iraq, such a move had the potential to create significant tensions within the community. At the time that the Conservation Plan was enacted, a request for at least one new memorial (from the Burma Star Association) had already been received.

Indeed, there was a rapid sequence of memorial installations on the site following the Conservation Plan, including the Royal Naval, Burma Star Association, Royal Marines, and Royal Air Force memorials, which were all erected between 2008 and 2011. The rededication of the Cenotaph in 2013 with an inscription designed to incorporate all service personnel regardless of role, status, or gender appears to be an attempt to, once again, wrest control from local interest groups. As in the beginning, control of the site, who can be officially memorialised there, and how this may be done, remain ultimately at the discretion of Hull City Council.

\section{CONCLUSION: POTENCY OF COMMEMORATIVE PLACE}

Throughout the past century the open area of space of Paragon Square in Kingston upon Hull has undergone a slow, irrevocable, transformation. The processes of memorialisation evident in the square have created a powerful, yet everyday, place, in which the remembering of past and present conflicts has become indelibly imprinted in the collective memory of the local community. The memorials within Paragon Square are not fixed. Modifications have been made to the inscriptions, appearance, and position of the memorials in this commemorative space since the first modifications were made to the South African War Memorial in the wake of the First World War.

\footnotetext{
${ }^{63}$ King (1998).
} 
The process of elaborating existing memorials, renegotiating and reinterpreting them, is one observed in memorial spaces throughout human history. Through these processes, the right to be remembered is actively contested. Each generation not only projects their understanding of past and current conflicts onto the existing memorials, but actively reshapes them to imbue them with fresh relevance. Who gets to control remembrance remains a point of contention, which can be read in biographies of the monuments themselves. The biographical approach to studies of space, place, and memorialisation inform our understanding of these tensions and highlights the ways in which individual and collective decisions may drive the formations and reformations of collective memory in urban spaces.

Acknowledgements: The author is grateful to Professor Malcolm Lillie, Dr Nicholas J. Evans, and Dr Jeanny Macleod for their comments on earlier drafts of this article.

\section{REFERENCES}

Ashplant, T. G., Dawson, Graham \& Roper, Michael (2013), The Politics of War Memory and Commemoration (London, Taylor \& Francis). https://doi.org/10.4324/9780203770115

Banton, Simon (no date), 'The Stones of Stonehenge, Barrow Map'. http://web.org.uk/barrowmap/ Bilton, David (2015), Hull in the Great War, 1914-1919 (Barnsley, Pen \& Sword Military).

Briggs, Asa (1988), Victorian Things (London, Batsford).

Burma Star Association (no date), 'Burma Star Association'. https://www.burmastar.org.uk/

Campbell, James (2016), 'Permission Granted for Memorial', Hull Daily Mail, 17 October.

Conan Doyle, Arthur (1900), The Great Boer War (London, Smith, Elder \& Co.).

Donaldson, Peter, (2013), Remembering the South African War (Liverpool, Liverpool University Press).

Evans, Michael (1998), 'Bevin Boys Paid Their Public Tribute at Last', The Times, 9 November.

Evans, Nicholas J. (2018), 'Re-remembering the First World War', paper presented at Remember Me: The Changing Face of Memorialisation, 4-7 April, University of Hull.

Farwell, D. E. \& Molleson, T. I. (1993), Excavations at Poundbury, Dorset 1966-1980. Volume 2: The Cemeteries (Dorchester, Dorset Natural History and Archaeological Society).

Gosden, Chris \& Marshall, Yvonne (1999), 'The Cultural Biography of Objects', World Archaeology, 31(2): 169-78. https://doi.org/10.1080/00438243.1999.9980439

Gregory, Adrian (2014), The Silence of Memory: Armistice Day, 1919-1946 (London, Bloomsbury).

Hampel, Philip (2007), 'Proposed Conservation Management Plan for the Memorial Garden at the Cenotaph, Paragon Square, Hull', (Hull, Hull City Council).

Hennessey, T. (2015), Britain's Korean War: Cold War Diplomacy, Strategy and Security 1950-53 (Mancester, Manchester University Press).

Hull Daily Mail (1903), 'City and County of Kingston-Upon-Hull', 3 February.

Hull Daily Mail (1923a), 'The Cenotaph Site: Paragon Square to Have Two Memorials', 10 January.

Hull Daily Mail (1923b), 'Hull Cenotaph Design', 22 August.

Hull Daily Mail (1946a), 'Cenotaph: Raids-Plaque Suggestion’, 10 October.

Hull Daily Mail (1946b), 'Hull Pays Tribute to Heroes of Two Wars', 11 November.

Hull Daily Mail (2006), 'Dignified Ceremony to Reveal Memorial', 26 May. 
Hull Daily Mail (2010), 'At Last, a Fitting Tribute to Brave Fallen Marines', 23 September.

Hull Daily Mail (2013), 'Normandy Veterans Meet', 1 June.

Hull Daily Mail (2018), 'Hull's Stunning People's Memorial to Victims of World War Two Blitz Bombing Raids to be Unveiled', 11 May.

https://www.hulldailymail.co.uk/news/hull-east-yorkshire-news/hull-peoples-memorial-blitzvictims- 1556818

Hull People's Memorial, 'Hull People's Memorial'. http://www.hull-peoples-memorial.co.uk/ Humber, John (1946), 'Remembrance Ceremony Unveiling', Hull Daily Mail, 4 November.

Inall, Yvonne (2018), 'Shine a Light: The Role of Light in Memorialisation Practices', paper presented at Remember Me: the Changing Face of Memorialisation, 4-7 April, University of Hull.

Ingold, Tim (2010), 'The Temporality of the Landscape', in R.W. Preucel \& S.A. Mrozowski (eds) Contemporary Archaeology in Theory: The New Pragmatism (Chichester, Wiley), 59-76.

Joy, Jody (2009), 'Reinvigorating Object Biography: Reproducing the Drama of Object Lives', World Archaeology, 41(4): 540-56. https://doi.org/10.1080/00438240903345530

King, Alex (1998), Memorials of the Great War in Britain: The Symbolism and Politics of Remembrance (Oxford, Berg).

Kopytoff, Igor (1986), 'The Cultural Biography of Things: Commoditization as Process', in Arjun Appardurai (ed.) The Social Life of Things: Commodities in Cultural Perspective (Cambridge, Cambridge University Press), 64-91. https://doi.org/10.1017/CBO9780511819582.004

Kuria, Ben (2010), 'Veteran Royal Marines Pay Tribute to Fallen Comrades at Unveiling of New Plaque', Hull Daily Mail, 23 September.

Lambert, Andrew D. (1996), 'Seizing the Initiative: The Arctic Convoys 1944 45', in N. A. M. Rodger (ed.) Naval Power in the Twentieth Century (London, Palgrave Macmillan), 151-62. https://doi.org/10.1007/978-1-349-13860-9_12

Levy, James (2003), 'The Needs of Political Policy Versus the Reality of Military Operations: Royal Navy Opposition to the Arctic Convoys, 1942', Journal of Strategic Studies, 26(1): 36-52. https://doi.org/10.1080/01402390308559307

Login, Emma (2016), Set in Stone? War Memorialisation as a Long-term and Continuing Process in the UK, France and the USA (Oxford, Archeopress). https://doi.org/10.2307/j.ctvxw3p0m

Moriarty, Catherine (1997), 'Private Grief and Public Remembrance: British First World War Memorials', in Martin Evans \& Kevin Lunn (eds) War and Memory in the Twentieth Century (Oxford, Berg), 125-42.

Nora, Pierre (1989), 'Between Memory and History: Les Lieux De Mémoire', Representations, 26: 7-24. https://doi.org/10.1525/rep.1989.26.1.99p0274v

Parker Pearson, Michael (2012), Stonehenge: Exploring the Greatest Stone Age Mystery (London, Simon \& Schuster).

Pettitt, Paul B. (2011), The Palaeolithic Origins of Human Burial (London, Routledge). https://doi.org/10.4324/9780203813300

Ritchie, Mandy (2000), 'Following Protracted Negotiations since 1989 with Kingston Upon Hull City Council, I Have Recently Been Informed That a Plaque Has Now Been Positioned at the War Memorial in Paragon Square in Memory of the Four Recipients of the Victoria Cross Who Lived in Hull', Hull Daily Mail, 2 February.

Royal Navy, (2013), 'Arctic Convoy Heroes Can Begin Applying for Their WW2 Campaign Medal Now', Ministry of Defence.

https://www.royalnavy.mod.uk/news-and-latest-activity/news/2013/february/26/130226-arcticconvoy-heroes-can-begin-applying-for-their-ww2-campaign-medal-now

Smith, Melvin Charles (2008), Awarded for Valour: A History of the Victoria Cross and the Evolution of British Heroism (Basingstoke, Palgrave Macmillan). 
Stead, I. M. (1991), Iron Age Cemeteries in East Yorkshire: Excavations at Burton Fleming, Rudston, Garton-on-the-Wolds, and Kirkburn (London, English Heritage in association with British Museum Press).

Sutton, Debbie (2000), 'Hull's Four Victoria Cross Heroes Will Be Remembered Tomorrow with a Special Ceremony in Their Honour', Hull Daily Mail, 15 April.

The Times (1925), 'War Memorials: Exhibition at Imperial War Museum', 7 November, 15.

The Times (1950), 'Remembrance of Korea Dead', 9 November.

Thompson, Jenna (2010), 'Last Post Sounds for a Brave Band of Brothers', Hull Daily Mail, 25 October.

Thompson, Julian (2010), Forgotten Voices of Burma: The Second World War's Forgotten Conflict (London, Ebury Press).

Tringham, Ruth (1994), 'Engendered Places in Prehistory', Gender, Place and Culture, 1(2): 169-203. https://doi.org/10.1080/09663699408721209

Whitmore, Lucie (2018), “"A Matter of Individual Opinion and Feeling”: The Changing Culture of Mourning Dress in the First World War', Women's History Review, 27(4): 579-94. https://doi.org/10.1080/09612025.2017.1292631

Winter, Jay (1999), 'Remembrance and Redemption', in 'Constructions of Memory: On Monuments Old and New No. 9', Harvard Design Magazine. http://www.harvarddesignmagazine.org/issues/9/remembrance-and-redemption

Winter, Jay (2006), Remembering War: The Great War Between Memory and History in the Twentieth Century (New Haven, CT, Yale University Press).

Winter, Jay (2014), Sites of Memory, Sites of Mourning: The Great War in European Cultural History (Cambridge, Cambridge University Press). https://doi.org/10.1017/CBO9781107589087

Young, A. (2001), 'Cenotaph’s £100,000 Facelift', Hull Daily Mail, 13 October.

To cite the article: Yvonne Inall (2020), 'A biography of memory: layered memorialisation of military death at an urban cenotaph', Journal of the British Academy, 8(s3): 25-49. DOI https://doi.org/10.5871/jba/008s3.025

Journal of the British Academy (ISSN 2052-7217) is published by The British Academy, 10-11 Carlton House Terrace, London, SW1Y 5AH www.thebritishacademy.ac.uk 
